\title{
Impact of COVID-19 on Indian Stock Market
}

\author{
Rajani B Bhat \\ Assistant Professor, Post Graduate and Research Department of Commerce \\ The Cochin College, Kochi, Kerala, India \\ V N Suresh \\ Associate Professor and Head, Post Graduate and Research Department of Commerce \\ Maharajas College, Ernakulam, Kerala, India
}

OPEN ACCESS

Manuscript ID:

COM-2021-09034092

Volume: 9

Issue: 3

Month: July

Year: 2021

E-ISSN: 2582-6190

Received: 10.05.2021

Accepted: 14.06.2021

Published: 01.07.2021

Citation:

Bhat, Rajani B., and V. N. Suresh. "Impact of Covid-19 on Indian Stock Market." ComFin Research, vol. 9, no. 3, 2021, pp. 30-36.

\section{DOI:}

https://doi.org/10.34293/ commerce.v9i3.4092

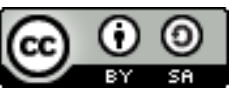

This work is licensed under a Creative Commons Attribution-ShareAlike 4.0 International License

\section{Abstract}

The corona virus outbreak, which originated in China, has infected nearly 8, 75,000 people. Its spread has left businesses around the world counting costs. The corona virus is going global, and it could bring the world economy to a standstill. COVID-19 that began in the depths of China's Hubei province is spreading rapidly, persuading the World Health Organisation to declare it as a pandemic. There are now significant outbreaks from South Korea to Italy and Iran, from America to Britain. The ongoing spread of the new corona virus has become one of the biggest threats to the global economy and financial markets. Even though, time and again our Indian economists have assured the country that Indian economy stands relatively insulated from the global value chain, but being integrated into world economy, there has to be some impact. This was reflected in the Nifty when the stock market took a great plunge down in last week of February, 2020. The present study is an attempt to examine the impact of COVID-19 on Indian Stock market. The study takes into consideration a time period of four months, from December 1st, 2019 to March 31st, 2020. The study focuses on the Nifty and sectoral indices of Nifty along with India Volatility Index. Tools used for the study involves correlation, regression, ANOVA, variance analysis and moving averages. The study concludes with the statement that volatility is higher in medium run than in short run and also there is significant impact of COVID-19 on Indian stock market.

Keywords: Corona, Indian Stock Market, Nifty, Sectoral Indices, Volatility, Volatility Index

\section{Introduction}

A virus named Severe Acute respiratory syndrome corona virus 2 (SARSCoV-2) causes corona virus disease (COVID-19). It has recently spread from the Wuhan City in Hubei province of China. According to the Situation Report of World Health Organisation (WHO) as on 31st March, 2020 7, 50,890 cases have been confirmed, with 57,610 new cases confirmed in the last twenty four hours. The total number of deaths reported as on 31st March, 2020 amounts to 36,398 with 3,301 deaths reported in the last twenty four hours. Coming to the Indian scenario, the country as on 31st March, 2020 has reported 1,071 confirmed cases with 29 deaths, with no new cases or deaths reported in the last twenty four hours. WHO, in the mid-January declared global health emergency because there was a chance this epidemic becoming pandemic if it was not contained.

In this modern world all the economies of the world are closely integrated. That is if anything happens in any part of the world it would have medium to high level of impact throughout the world. So effect on one of the biggest economies like China would significantly impact all the economies of the world. China is the 2nd biggest economy of the world, worth $\$ 13.6$ trillion. 
Its position is just after USA. About $16 \%$ of the total World's GDP is contributed by China. Many companies are dependent on China for forward \& backward linkage. Due to the factory closures of China the production of many important companies has stopped. China is not only important for its supply of goods \& service it has also great deal of Consumers with significant purchasing power, due to which many international brands executes in China. (Mahmud, 2020)

The virus, first detected in the Chinese city of Wuhan last December, has infected more than $8,75,000$ people in more than 200 countries and territories globally, according to the World Health Organization. The place of origination of this pandemic, China the cases reported amounted to 82,545 with 3,314 deaths reported as on 31st March 2020. But very soon, Italy surpassed the position of China by reporting 1,01,739 confirmed cases and 11,591 deaths. The second most hit country is Spain with 85,195 cases confirmed and 7,340 deaths reported. The third worst hot country is France with 43,977 cases confirmed and 3,017 deaths reported. (COVID-19 Situation Reports of WHO on 31st March, 2020). To contain the COVID-19 outbreak, World Health Organisation authorities had ordered for complete lock down of cities, social distancing, restricted movements of millions and suspended business operations - moves that will slow down and drag down the global economy along the way.

Referencing financial data, current and historical, it is seen that the pace that COVID-19 is spreading much faster than prior epidemics (SARS, swine flu) in a limited time frame. The timing of this contagion has also been an issue to deal with. China has been working to see an economic recover from a tepid 2019 and the first wave of trade negotiations with the U.S. were just underway. The effect of imports to China has directly affected the export economy of countries around the world. This has an immediate effect within oil, LNG, agricultural goods and metals. In oil, it is clearly evident that demand from China, the largest net importer of crude oil, take away nearly ten percent of global demand in January.

This outbreak has climbed rapidly and its only four months into the move. The number of cases reported are moving quickly above $8,75,000$ worldwide with the fatality numbers topping 36,000 in total. As this continues to make its way through quarantines and economic isolations, the impact seems to be rising at a compounded rate. The most important part of this pandemic and its financial and social implication is that people need to be aware. There is a high chance that this continued pressure and spreading contagion will push the global economy into recession.

With a focus on the financial and commodity markets, the key to maintaining balance is to stay informed. Watching currency markets are as important as covering import and exports of commodities. There is no way to predict such a 'black swan' event, but a comparison with prior markets as they make their way through these critical anomalies is possible. As everything in this world is a new news event, everything follows a cycle that is familiar. The research question posed in this regard in the study is as:

- To examine the impact of COVID-19 on Indian Stock Market.

- To study the volatility of Indian Stock market in short run and medium run during the impact of COVID-19.

In order to achieve these objectives, the hypotheses set forth are:

- $\mathrm{H}_{01}$ : There is no significant impact of COVID-19 on Indian Stock Market.

- $\mathrm{H}_{02}$ : There is no difference in volatility in short run and medium run during the impact of COVID-19.

\section{Methodology of the Study}

The study takes the form of descriptive and empirical in nature. The data for the study has been taken from secondary sources of NSE website. The closing prices of Nifty, Nifty Sectoral indices and India Volatility Index (VIX) have been collected for examining the impact of COVID-19 on Indian Stock market. The indices considered for the study are - Nifty, Sectoral indices of Nifty such as - auto, bank, financial services, FMCG, IT, media, metal, pharma, private banks, PSU banks, reality, Nifty commodities, Nifty 50 Futures Index, Nifty 500 Value 50 and India Volatility Index. The period of the study is for four months, ranging from 1st December, 2019 to 31 st March, 2020. The natural log of closing 
prices is calculated and there in the returns of Nifty is found out using the formula; Returns $=\log$ $\left(\mathrm{R}_{\mathrm{t}}-\mathrm{R}_{\mathrm{t}-1}\right)$

One of the objectives of the study is to examine the volatility in short run and medium run during the time period under study. For this purpose, short run period implies three days and medium run implies ten days. Average returns for short run and medium run is calculated. Statistical tools of correlation, regression and ANOVA has been used in order to achieve the first objective of examining the impact of corona on Indian Stock Market. MS Excel has been adopted for the same. To study the volatility in short run and medium run, variance analysis is done using moving averages.

\section{Data Analysis and Interpretation}

\section{Objective 1 - To Examine the Impact of COVID-19} on Indian Stock Market

The hypothesis put forward for this is $\mathrm{H}_{01}$ : There is no significant impact of COVID-19 on Indian Stock Market. For the purposes of fulfilling this objective, the variables considered are closing prices of Nifty and Volatility Index (VIX). Nifty represents the sentiments and mood of the Indian Stock market and Volatility Index is described as the barometer of fear in the market. As and when there is any uncertainty in the market, the VIX goes up. In such a case, there should be a strong negative correlation between these two variables. The tools used for this purpose are correlation, regression and ANOVA test. These tests have been done by using MS Excel. The result statistics are as follows:

\section{Results of Correlation}

Table 1 presents the test results of correlation. The value of correlation co-efficient as seen as in the table is -0.98691 . This confirms the statement that Volatility Index and Nifty are highly inversely correlated. Volatility Index is described as the barometer of the fear of investors in the stock market. Whenever the market is hit with sensitive information, it will be reflected on Nifty as well as VIX. If the information has a positive impact, then Nifty will take a plunge upwards and VIX, takes a downward plunge and vice versa. This fact is evident from the results in Table 1.

Table 1: Correlation Test Statistics Results

\begin{tabular}{|c|c|c|}
\hline & Column 1 & Column 2 \\
\hline Column 1 & 1 & \\
\hline Column 2 & -0.98691 & 1 \\
\hline
\end{tabular}

Source: Compiled by Researcher

\section{Results of Regression}

Table 2: Regression Test Statistics Results

\begin{tabular}{|l|c|}
\hline \multicolumn{2}{|c|}{ Regression Statistics } \\
\hline Multiple R & 0.986911 \\
\hline R Square & 0.973994 \\
\hline Adjusted R Square & 0.973681 \\
\hline Standard Error & 3.212251 \\
\hline Observations & 85 \\
\hline
\end{tabular}

Source: Compiled by Researcher

Table 2 provides the regression test results. The co-efficient of determination, $\mathrm{R}^{2}$ displays a very high value of 0.973994 depicting the goodness of fit. Statistically speaking, higher the correlation coefficient, better is the fit as per regression equation. $\mathrm{R}^{2}$ measures the overall accuracy of regression. This co-efficient interprets the accuracy of predictor of independent variable on the dependent variable value. This test is better read with the $\mathrm{F}$ value of ANOVA.

\section{Results of ANOVA}

Table 3: Test Results of ANOVA

\begin{tabular}{|c|c|c|c|c|c|}
\hline \multicolumn{7}{|c|}{ ANOVA } \\
\hline & Df & SS & MS & F & Significance F \\
\hline Regression & 1 & 32076.31 & 32076.31 & 3108.605 & $1.49 \mathrm{E}-67$ \\
\hline Residual & 83 & 856.4401 & 10.31855 & & \\
\hline Total & 84 & 32932.75 & & & \\
\hline
\end{tabular}

Source: Compiled by Researcher 
Table 3 depicts the test statistics of ANOVA. Higher the co-efficient of determination, higher should be the value of $\mathrm{F}$ statistic, in order to validate the results of regression equation. As it is evident from Table 3, F statistic comes with a very high value of 3108.605 . The $p$ value is highly negligible arriving at the conclusion to fail to accept the null hypothesis

Hence, it can be concluded that there is a significant impact of COVID-19 on Indian Stock Market. This leads the study to next objective of whether there exists volatility during the short run or medium run during this crisis time.

Objective II - To Study the Volatility of Indian Stock Market in Short Run and Medium Run During the Impact of Corona Virus

For this, hypothesis put forward is $\mathrm{H}_{02}$ : There is no difference in volatility in short run and medium run during the impact of corona virus.

The volatility is calculated using moving average method using variance analysis. In order to achieve this objective, the natural log of closing prices is calculated and there in the returns of Nifty is found out using the formula; Returns $=\log \left(\mathrm{R}_{\mathrm{t}}\right.$ $-\mathrm{R}_{\mathrm{t}-1}$ ). Thereafter, moving average for three days, considered in the study as short run and ten days, taken as medium run is calculated. Using MS Excel, standard deviation of two series, moving average for three days and moving average for ten days is calculated. From the value obtained, variance is calculated. Theoretically speaking, higher variance implies higher volatility.

Table 4 presents the result values of variance computed for two series.

Table 4: Computation of Variance for two series

\begin{tabular}{|c|c|c|c|c|c|c|c|}
\hline $\begin{array}{c}\text { Log Closing } \\
\text { prices }\end{array}$ & Log returns & \multicolumn{3}{|c|}{ Average returns for 3 days } & \multicolumn{2}{c|}{ Average returns for 10 days } \\
\hline 4.080922168 & & & & & & & \\
\hline 4.078971286 & -0.001950882 & & & & & & \\
\hline 4.080741899 & 0.001770612 & & & & & & \\
\hline 4.079846654 & -0.000895244 & -0.0003585 & 0.00606755 & 0.07789451 & & & \\
\hline 4.076330903 & -0.003515751 & -0.00088013 & 0.00610302 & 0.07812183 & & & \\
\hline 4.076913385 & 0.000582481 & -0.00127617 & 0.00614048 & 0.07836124 & & & \\
\hline 4.073967494 & -0.00294589 & -0.00195972 & 0.00617932 & 0.07860866 & & & \\
\hline 4.075917231 & 0.001949737 & -0.00013789 & 0.00621931 & 0.07886263 & & & \\
\hline 4.078159453 & 0.002242222 & 0.00041536 & 0.00625679 & 0.0790999 & -0.000715 & 0.003911 & 0.062542 \\
\hline 4.082307743 & 0.00414829 & 0.00278008 & 0.0062925 & 0.07932531 & -0.000345 & 0.003935 & 0.062732 \\
\hline 4.081129386 & -0.001178357 & 0.00173738 & 0.00631061 & 0.07943936 & 0.000154 & 0.003958 & 0.062911 \\
\hline 4.085112113 & 0.003982728 & 0.00231755 & 0.00633826 & 0.07961322 & $2.07 \mathrm{E}-05$ & 0.003977 & 0.063066 \\
\hline 4.087129842 & 0.002017729 & 0.00160737 & 0.00636087 & 0.07975505 & 0.000614 & 0.003998 & 0.06323 \\
\hline 4.088479843 & 0.001350001 & 0.00245015 & 0.00638992 & 0.07993696 & 0.000639 & 0.004014 & 0.063357 \\
\hline 4.088908269 & 0.000428426 & 0.00126539 & 0.00641119 & 0.08006993 & 0.000863 & 0.00403 & 0.063482 \\
\hline 4.088587874 & -0.000320394 & 0.00048601 & 0.00644341 & 0.08027087 & 0.001258 & 0.004043 & 0.063588 \\
\hline 4.086877472 & -0.001710403 & -0.00053412 & 0.00648169 & 0.08050896 & 0.001167 & 0.004052 & 0.063657 \\
\hline 4.083737262 & -0.00314021 & -0.00172367 & 0.0065261 & 0.08078428 & 0.001291 & 0.004062 & 0.063731 \\
\hline 4.087987162 & 0.0042499 & -0.00020024 & 0.00657487 & 0.08108557 & 0.000782 & 0.004069 & 0.063788 \\
\hline 4.088343437 & 0.000356275 & 0.00048866 & 0.00661966 & 0.08136131 & 0.000983 & 0.004082 & 0.063894 \\
\hline 4.085235262 & -0.003108175 & 0.00049933 & 0.00666117 & 0.08161602 & 0.000604 & 0.004093 & 0.063977 \\
\hline 4.08573642 & 0.000501158 & -0.00075025 & 0.00670334 & 0.08187391 & 0.000411 & 0.004108 & 0.064095 \\
\hline 4.089276165 & 0.003539745 & 0.00031091 & 0.00675345 & 0.0821794 & $6.24 \mathrm{E}-05$ & 0.004125 & 0.064229 \\
\hline
\end{tabular}


ComFin Research

\begin{tabular}{|c|c|c|c|c|c|c|c|}
\hline 4. & 5 & 4 & & & & 6 & 0.064393 \\
\hline 4.078 & 836 & .00226893 & & & -0.000117 & 0.004166 & 064544 \\
\hline 55 & 11 & 76 & 948 & 309 & 998 & 39 & 24 \\
\hline 4.08 & -0.00099563 & -000240325 & 000605860 & 008341877 & -0.000749 & .00422 & 0.064963 \\
\hline & & & & & & & \\
\hline 4.0 & & & & & & & \\
\hline 4.09 & 127 & & & & & 0.004299 & 0.065569 \\
\hline 279 & 52 & & & 033 & & & 065744 \\
\hline 85 & 994 & 6 & 75 & 47 & 6 & 42 & 396 \\
\hline 325 & 0.00 & 37 & 46 & 883 & 0.0 & 56 & 997 \\
\hline 4.09 & -0.000 & & & & & & \\
\hline & -0.00 & & & & & & \\
\hline & & & & & & & \\
\hline & & & & & & & \\
\hline 59768 & 0.002626813 & & & & & & \\
\hline 4.0 & 274 & 0.0 & 31 & 443 & 127 & 42 & 648 \\
\hline & -0.0 & & & & & & \\
\hline 4. & 1 & 1 & & & & & 66 \\
\hline & 54 & 38 & & & & & \\
\hline & -0.003367936 & -0.00099727 & & & & & \\
\hline & -0.002667534 & -0.00112 & & & & & \\
\hline $4 .($ & -0.0 & 82 & & 3 & -0 . & & 008 \\
\hline & 0.00 & & & & & & \\
\hline 4.07 & 25 & & & & & & \\
\hline 4.0 & 36 & 4 & 0 & 72 & -0. & 71 & 972 \\
\hline 4.084145344 & 78 & 11 & 2 & 5 & -0. & & 84 \\
\hline 26144 & 92 & 0.00 & 35 & 0.09089197 & -0.000393 & 26 & 68 \\
\hline 19775 & 0.002406369 & 0602 & & 2238 & & & 653 \\
\hline & & & & & & & \\
\hline & & & & & & & \\
\hline 4.085 & 061 & 24 & & & & & \\
\hline 4.083267851 & -0.002188634 & $6.6342 \mathrm{E}-05$ & 0.00863608 & 0.0929305 & 0.000765 & 0.004869 & 0.069777 \\
\hline 4.080835648 & -0.002432203 & -0.00185563 & & 0.09342164 & & 0.004832 & 0.069512 \\
\hline 4.07890 & -0.001925921 & -0.00218225 & .00885643 & 0.09410863 & 0.001236 & .004737 & 068825 \\
\hline 4.083 & 0.0 & 0 & & & & & 29 \\
\hline 4.08 & -0.0 & 0.00 & 446 & & 0.0 & & 738 \\
\hline 4.072962717 & -0.009134775 & -0.00198234 & 0.00918646 & 0.09584603 & -0.000205 & & 0.067175 \\
\hline 4.07 & -0.00115 & -0.00 & & 766 & -0.000976 & 4433 & 583 \\
\hline 4.067387065 & -0.004417646 & -0.00490348 & & & -0.000852 & & 0.066157 \\
\hline 4.065 & -0.0 & -0.0 & & & -0.0 & & 494 \\
\hline 4.049285876 & -0.01 & -0.00 & & & -0 & 22 & 0.064973 \\
\hline 4.046602457 & -0.002683419 & -0.0069282 & 0.01016621 & 0.10082763 & -0.003617 & 0.004161 & 0.064506 \\
\hline 4.053205254 & 0.006602798 & -0.00416589 & 0.01042996 & 0.10212717 & -0.003667 & 0.004173 & 0.064601 \\
\hline
\end{tabular}


ComFin Research

\begin{tabular}{|c|c|c|c|c|c|c|c|}
\hline 4.051191125 & -0.00201413 & 0.00063508 & 0.01070027 & 0.10344211 & -0.002763 & 0.004177 & 0.06463 \\
\hline 4.051885379 & 0.000694254 & 0.00176097 & 0.01085822 & 0.10420278 & -0.002772 & 0.004098 & 0.064012 \\
\hline 4.040975957 & -0.010909421 & -0.00407643 & 0.01095662 & 0.10467389 & -0.003183 & 0.003975 & 0.06305 \\
\hline 4.019176547 & -0.02179941 & -0.01067153 & 0.0112755 & 0.10618618 & -0.004112 & 0.003835 & 0.061925 \\
\hline 4.019465248 & 0.000288701 & -0.01080671 & 0.01164605 & 0.10791685 & -0.005379 & 0.003727 & 0.061046 \\
\hline 3.9818254 & -0.037639848 & -0.01971685 & 0.0120526 & 0.10978432 & -0.005234 & 0.003692 & 0.060762 \\
\hline 3.998049989 & 0.016224589 & -0.00704219 & 0.01199231 & 0.1095094 & -0.008556 & 0.003595 & 0.059957 \\
\hline 3.963665075 & -0.034384915 & -0.01860006 & 0.01252413 & 0.11191127 & -0.006765 & 0.003737 & 0.061129 \\
\hline 3.952649591 & -0.011015483 & -0.00972527 & 0.01249535 & 0.11178258 & -0.008562 & 0.003747 & 0.061215 \\
\hline 3.927821877 & -0.024827715 & -0.02340937 & 0.01307349 & 0.11433935 & -0.009395 & 0.0039 & 0.062452 \\
\hline 3.917161404 & -0.010660473 & -0.01550122 & 0.01195178 & 0.10932419 & -0.012538 & 0.004127 & 0.064245 \\
\hline 3.941782161 & 0.024620758 & -0.00362248 & 0.0116133 & 0.10776503 & -0.013403 & 0.004411 & 0.066413 \\
\hline 3.881398924 & -0.060383237 & -0.01547432 & 0.01246469 & 0.11164537 & -0.01101 & 0.004663 & 0.068288 \\
\hline 3.892153061 & 0.010754138 & -0.00833611 & 0.01132412 & 0.10641484 & -0.015958 & 0.005199 & 0.072103 \\
\hline 3.920011084 & 0.027858023 & -0.00725703 & 0.01089074 & 0.10435871 & -0.012702 & 0.004576 & 0.067648 \\
\hline 3.936586621 & 0.016575537 & 0.0183959 & 0.0088791 & 0.09422896 & -0.009945 & 0.004016 & 0.063368 \\
\hline 3.937530429 & 0.000943808 & 0.01512579 & 0.00849312 & 0.09215811 & & & \\
\hline \multicolumn{8}{|l|}{3.918088029} \\
\hline \multicolumn{8}{|l|}{3.934384813} \\
\hline $\begin{array}{c}\text { Average } \\
\text { value }\end{array}$ & -0.00174868 & -0.00186045 & & & -0.001914 & & \\
\hline $\begin{array}{l}\text { Standard } \\
\text { Deviation }\end{array}$ & & & 0.00837564 & & & & 0.065635 \\
\hline Variance & & & 0.09151632 & & & & 0.256194 \\
\hline
\end{tabular}

Source: Compiled by Researcher

Table 4 depicts the computation of variance for two series - moving average for three days and moving average for ten days. The variance computed for three day period, considered in the study as short run, amounts to 9 percent whereas the variance for ten day period, named as medium run stands at 26 percent. This leads to the situation where the null hypothesis fails in getting accepted, implying there is a difference in volatility in short run and medium run during the impact of corona virus.

Higher variance implies higher volatility. Therefore, it can be concluded that the volatility is higher during the medium run than short run period.

\section{Conclusion}

Equity indices in Indian stock market notched up smart gains on the last day of 2019-2020, but ended deep in the red for the fiscal as the global corona virus pandemic triggered record-shattering sell offs in March. Nifty as well as Sensex, both the benchmarks posted their biggest ever one-day falls in March, in tandem with other global markets, as investors fled risky assets amid the Covid-19 outbreak. According to the traders, domestic investors turned positive amid rebound in global peers as most Asian benchmarks ended higher on recovery in China's manufacturing during March as authorities relaxed anti - disease controls and allowed the factories to reopen. Mirroring positive global market, Indian markets also reacted positively on the last day of the financial year. Almost all sectoral indices were up and volatility index was down by 10 percent. This point was proved in the above study by establishing a highly negative correlation between the closing prices of Nifty shares and Volatility Index.

The market always finds a way to establish the equilibrium through the process of price discovery. In order for better performance of the stock markets, there should be some viable amount of volatility. This again is point proved in the above study. 
Reports pouring in are favourable to India. This is because as the country is crossing the third stage of pandemic, the rate of cases confirmed has not grown exponentially high as it was in the case of China, Italy, Spain or France. This situation gives a small ray of hope for India. As for the financial sector, the performance of global market will be the key driver for Indian market in the near term.

\section{References}

Bora, Debakshi, and Daisy Basistha. "The Outbreak of COVID-19 Pandemic and its Impact on Stock Market Volatility: Evidence from a Worst-Affected Economy." Journal of Public Affairs, 2021.

"Coronavirus disease (COVID-19) Weekly Epidemiological Update and Weekly Operational Update." WHO, https://www. who.int/emergencies/diseases/novelcoronavirus-2019/situation-reports

Das, Nupur Moni, and Bhabani Sankar Rout. "Impact of COVID-19 on Market Risk: Appraisal with Value-at-risk Models." The Indian Economic Journal, vol. 68, no. 3, 2020, pp. 396-416.
Guru, Biplab Kumar, and Amarendra Das. "COVID-19 and Uncertainty Spillovers in Indian Stock Market." MethodsX, vol. 8, 2021.

Mahmud, Sakib. Impact of Corona Virus on Global Economy. 2020.

Ravi, S. "Impact of COVID-19 on the Indian Stock Markets." Business World, 2020.

Sahoo, Manamani. "COVID-19 Impact on Stock Market: Evidence from the Indian Stock Market." Journal of Public Affairs, 2021.

Shankar, Rishika, and Priti Dubey. "Indian Stock Market during the COVID-19 Pandemic: Vulnerable or Resilient?: Sectoral Analysis." Organizations and Markets in Emerging Economies, vol. 12, 2021, pp. 131-159.

Singh, Bhanwar, et al. "The Outbreak of COVID-19 and Stock Market Responses: An Event Study and Panel Data Analysis for G-20 Countries." Global Business Review, 2020.

Soni, Chetana M., et al. "Impact of COVID-19 Pandemic on Stock Market." PalArch's Journal of Archaeology of Egypt, vol. 18, no. 4, 2021.

\section{Author Details}

Dr. Rajani B Bhat, Assistant Professor, Post Graduate and Research Department of Commerce, The Cochin College, Kochi, Kerala, India, Email ID: rajanispai@gmail.com

Dr. S.V. Suresh, Associate Professor and Head, Post Graduate and Research Department of Commerce, Maharajas College, Ernakulam, Kerala, India, EmailID: snvichattu@gmail.com 